\title{
El exilio dentro y fuera: La Ciudad de Gonzalo Millán, I979 y 1994
}

Este artículo analiza algunas diferencias y particularidades de las dos ediciones del poemario La Ciudad de Gonzalo Millán, de 1979 y 1994 respectivamente, demostrándose importantes cambios en la última versión. Se explica cómo el poeta reconstruye, a través de la escritura, la patria que ha perdido a causa del exilio. Esta obra se vuelve, entonces, un mecanismo de sobrevivencia. La edición de los noventa da cuenta de un nuevo contexto social y político tras el retorno de la democracia a Chile, pero también de su latente permeabilidad textual, por lo que exilio y regreso se constituyen como un modo de constante reinvención.

Palabras claves: Gonzalo Millán, poesía chilena, dictadura, exilio

This article analyzes some of the differences and peculiarities of two editions (in 1979 and 1994) of the book of poetry La Ciudad by Chilean poet Gonzalo Millán, demonstrating important changes in the later version. The article attempts to explain the way in which the poet reconstructs, through writing, the homeland he lost while in exile. His poetry becomes a mechanism of survival. The 199o's edition gives an account of a new socio-political context after democracy's return to Chile. In addition, through the text's permeability, exile and repatriation become a constant mode of re-invention.

Keywords: Gonzalo Millán, Chilean poetry, dictatorship, exile

A doce años de la muerte del poeta chileno Gonzalo Millán (1947-2006), el más joven y una de las voces más prominentes de la generación de poetas del sesenta, resulta necesario revisitar uno de los poemarios más relevantes en su producción literaria, el libro La Ciudad. ${ }^{\mathrm{I}}$ De este modo, en este artículo me propongo analizar y comparar tanto la edición canadiense de 1979, como la de 1994, que fue ampliada y revisada por su autor, siendo publicada por la editorial Cuarto Propio en Santiago de Chile. Cabe señalar, también, que recientes esfuerzos editoriales han puesto en circulación una vez más este libro de Millán, entre otras, la edición de 2014 publicada en Madrid por Amargord Ediciones, que retoma la primera versión, de 1979.

REVISTA CANADIENSE DE ESTUDIOS HISPÁNICOS 4I.2 (OTOÑO 2OI7) 
La más reciente, de la editorial independiente La Joyita Cartonera, estuvo a cargo de Elizabeth Cárdenas, y fue prologada por Bárbara Fernández. Esta última está basada en la versión que Millán revisó a su regreso tras el exilio en Canadá.

Si bien la edición canadiense ha recibido la mayor atención, la de 1994 introduce importantes cambios, por cuanto agrega poemas que provienen de Seudónimos de la muerte (1984), además de algunas modificaciones menores, pero que enfatizan una nueva perspectiva de enunciación. Como ha planteado Francisco Leal, conviene preguntarse a qué se debe una mayor atención de la crítica sobre la primera edición. Posiblemente se deba a que se le ha considerado como la versión, la original, situada en el tiempo de contingencia de lo que trata; la segunda, en cambio, sería tan solo una reedición que presenta ciertas alteraciones. En mi lectura considero necesario desentrañar las nuevas constelaciones de sentido que nos presenta esta edición ampliada y revisada, puesto que dichos cambios demuestran una intención autorial de expresar que el texto no necesariamente es un todo acabado, y que su vigencia radica, precisamente, en esta capacidad de movilidad y transitoriedad que lo define. ${ }^{2}$ Además, los cambios responden a un nuevo escenario político y social, como también demuestran una decantación del pasado y una maduración de la vivencia del trauma dictatorial y de la experiencia del exilio.

Siguiendo lo anterior, en este artículo me interesa analizar cómo Millán representa la ciudad perdida (la patria), planteada como el ethos que anhela recuperar a través de un ejercicio de la memoria. La tensión formulada es la imposibilidad de reconstruirla materialmente, primero por causa de su propio exilio y, segundo, porque la patria ha sido destrozada, no solo física, sino también simbólicamente. En su texto "Sobre la construcción de La Ciudad", publicado en la ciudad de Concepción en I985, y donde explica la génesis de este libro, Millán señala: "La usurpación del poder, la pérdida de su tradición democrática y de la memoria de ésta, el olvido de los hábitos de la convivencia ciudadana, provocan una corrupción que se propaga a todos los niveles sin excluir el del lenguaje" (7). En su intento por recuperar el espacio de la ciudad, la voz poética denuncia la violencia política y las violaciones a los derechos humanos. El poder dictatorial se impone de manera omnipresente, por lo que en este texto hay un hondo sentimiento de pesimismo y de fracaso. Sin embargo, en la edición ampliada de I994, hacia el final del poemario, se atisba un clima de esperanza, por lo que se explicita que, bajo un nuevo contexto de producción de la obra (retorno de la democracia), la ciudad vislumbra un 
proceso más auspicioso, en que la reconstrucción de la ciudad se ha alcanzado y, por lo tanto, "se cierra el poema" (Millán I26).

LA CIUDAD ANTE LA CRÍTICA

La producción crítica en torno al poemario La Ciudad de Gonzalo Millán, ha sido más prolífica respecto a otras obras de este poeta chileno. Esto se puede explicar por tratarse de uno de los libros más importantes de la poesía chilena escrita durante el período dictatorial y, más específicamente, desde el exilio. El texto, en su conjunto, puede ser leído como un solo y extenso poema, dividido en secciones temáticas que recorren el estado de cosas y del mundo en la ciudad. Para su estudio, resultan fundamentales las aportaciones críticas tanto de Grínor Rojo, Naín Nómez, Carmen Foxley como de Soledad Bianchi y, más recientemente, de Francisco Leal. $^{3}$

Rojo ha sido uno de los primeros en señalar que el productor de $L a$ Ciudad permanece distanciado a fin de conseguir una imparcial "fundación imaginaria de esa Ciudad, símbolo de la cultura de un pueblo, y que no está muerta, sino en proceso de germinación latente" ("Poesía chilena" 23). En su libro sobre la crítica del exilio de 1987 , Rojo indica también que el intento del poeta obedece a los dictados de un impulso milenario, donde el hombre, la naturaleza y sus transformaciones responden al conjunto total que la palabra ciudad nombra. Así, Millán construye La Ciudad, y con esto, algunos rasgos distintivos de su poética. Al respecto, sostiene que el poeta, al encontrarse premunido de una experiencia vital donde la carencia constituye el origen, consigue "a través de su propio lenguaje un medio de rescate de la cuota de vida de la que la dictadura chilena lo priva" (Crítica del exilio 83 ). Al construir sobre la página el presente que la dictadura le ha arrebatado, logra fundir en La Ciudad la experiencia y el lenguaje del exilio; esto es, la experiencia y el lenguaje de la patria. Con esto, la escritura del libro, para Rojo, es análoga a la construcción de la ciudad e, igualmente, se cumple con esto la tarea de reconstruirle a la patria la cultura arrasada. Millán consigue, de este modo, edificar en el tiempo y el espacio en los que se sitúa, un doble perfecto de la ciudad que no tiene, es decir, la patria de la que ha sido desterrado.

Foxley, por su parte, señala que la monotonía de la técnica de coordinación de proposiciones referidas a hechos sociales negativos, atenuados o disimulados con afirmaciones heterogéneas sobre el tiempo y la naturaleza, pese a las críticas de muchos lectores, logra "desplegar un campo de fuerzas subjetivas y una fuerte energía latente $\mathrm{y}$ progresivamente emergente, mucho más allá incluso de unos personajes que deambulan maquinalmente y retenidos en sus ocupaciones 
habituales" ("La negatividad" 78). De tal manera, se produce una dinámica encantatoria gracias a esa monotonía. Pero, a su vez, el discurso poético va adquiriendo un tono dramático, donde se conjura e intenta revertir la condición de excluidos de un proceso histórico y cultural. Foxley señala que, sobre la base de proposiciones yuxtapuestas, el hecho del relato impide el avance de los personajes, creando así una ilusión de secuencialidad, pero este vuelve a sí mismo y paraliza a los habitantes de la ciudad. Con esto se exhibe el aspecto fragmentario y acumulativo respecto del estado del mundo y de las cosas, evidencia que hace aflorar un clima de negatividad que, sin embargo, se revierte gracias a los síntomas de vida que permiten su regeneración. Las circunstancias producen un estado de emergencia constante, en un contexto social y político también de emergencia histórica. La acción del verbo, en este sentido, constituye el elemento de la proposición que vincula al lenguaje no solo con la realidad, sino que permite la cohesión e 'ilusión de vida' a nivel de representación mimética de dicha realidad.

Nómez, por otro lado, considera como eje de su análisis el tema del exilio. Señala que este constituye el hecho de vivir una vida impuesta en un medio ajeno y extraño, es decir, el no tener un pasado ni una biografía en el nuevo país. De este modo, explica que los escritores exiliados se convierten en verdaderos analistas del fenómeno que viven, transformándolo en un territorio personal. Ellos se ven obligados a buscar los puntos de encuentro entre pasado y presente, tanto en sus creaciones literarias como en sus vidas cotidianas. A su vez, la dictadura es un tema que se transforma para ellos en una obsesión, por cuanto se presenta un rechazo a representar el aquí y el ahora. Respecto al extenso poema que compone $L a$ Ciudad, Nómez señala que este es un texto cerrado y abierto. Cerrado porque es un discurso ficticio pronunciado por un anciano, quien es a la vez el protagonista de dicho discurso. ${ }^{4}$ Abierto, debido al tipo de discurso en montaje, y dada la posibilidad de leerlo de atrás para adelante sin perder el sentido. El libro, de tal manera, es un poema que alude al pasado caído, pero esto "en la forma de asumpción crítica de un lenguaje que señala a la realidad para transformarla" (15). De este modo, para Nómez, el poema narra la fundación, construcción y destrucción de la ciudad, tanto real como simbólica, es decir, la de la patria. No obstante, a mi juicio, considerar que en el poemario se narra la fundación de la ciudad, en el contexto de una resistencia al presente, reduce la apuesta artística y política de La Ciudad, limitando su función literaria a mero ejercicio testimonial. Nómez agrega que, desde sus comienzos, la destrucción se va amplificando y se concreta la tragedia de una ciudad destruida por el tirano. Sin embargo, señala, como en los ciclos de la naturaleza, el hombre 
se vuelve sobre sus propias heridas, y logra, como el ave fénix, rehacerse desde las cenizas. Finalmente, expresa que el texto podría entenderse como panfletario, pero su valor literario lo vuelve multívoco $\mathrm{y}$, por tanto, recupera el sentido de pluralidad.

Bianchi, por su parte, hace un recorrido sobre varios libros de Millán, dando cuenta de los rasgos que comparten entre sí. Respecto a La Ciudad, señala que la complejidad "se agudiza porque todo el texto refiere unitariamente a ese espacio ciudadano y porque, además, su autor es un anciano cuya muerte se corresponde con el final del poema y del libro construido en y por la lectura" (3). También se refiere al uso del lenguaje, es decir, a la precisión con que cada palabra es escogida, de tal forma cada significante y significado posee un valor concienzudamente atribuido. Bianchi da cuenta, así, sobre la trayectoria del poeta, analizando el tránsito desde su ópera prima Relación personal (1968), pasando por Seudónimos de la muerte (1984), Vida (1984) y, finalmente, poemas de Virus (1987). Es decir, su aproximación es de tipo comparativa. Señala, por ejemplo, que tanto La Ciudad como Virus son atravesados por una temática particular y contundente, y en ocasiones con distinto énfasis en el tratamiento. Se refiere, finalmente, al ingenio e ironía que Millán utiliza, los que además concentran una gran intensidad en su escritura.

Por otro lado, en su artículo "El regreso de los muertos", Leal parte con dos advertencias al lector. Estas son: primero, no caer en el prejuicio de ver necesariamente La Ciudad como un producto del Estado dictatorial, que inevitablemente condiciona su hermenéutica. Segundo, no se debe pensar que el tema de la postdictadura, analizado frecuentemente por la academia, sea un tema ya agotado. Hechas estas salvedades, se da a la tarea de analizar el ambiente sociopolítico que cultiva la aparición de La Ciudad. Examina también aspectos relacionados con el aparato ideológico que subyace en todo sistema totalitario y que repercute sobre la base simbólica en la sociedad. Esto último, lo analiza considerando el caso chileno, para luego ver de qué manera se plasma dentro del poemario, señalando que su interés está en que "[l]a vuelta de La Ciudad no tiene que ver necesariamente con un trabajo de la memoria (tan aplaudida) sino con una denuncia de lo que el presente tuvo que hacer desaparecer para constituirse como tal" ("El regreso"). Además, da cuenta de que este libro no es un catastro sobre las fechorías dictatoriales, sino que su importancia radica en la apertura a lo político, entendiendo esto último como una lucha emancipatoria. Aquí se cruzan, según el autor, lo político y la poesía, instalando de ese modo una sutura, que no se hace necesariamente por medio de la denuncia. Pero la importancia de esta poesía radica, precisamente, en la necesidad de establecer una mirada hacia la herida que 
ha dejado la historia reciente, y así, se establece una lucha por recordar el sufrimiento producido por el terrorismo de Estado. En este aspecto, Leal se contradice, ya que paradójicamente analiza La Ciudad desde el mismo punto de vista que critica al comienzo del artículo, es decir, analizando el poemario como un producto de la dictadura, es decir, enfatizando su dimensión testimonial. De tal modo, precisa, este es un gesto de revivir a los muertos, aplastados por dicha causa, por lo que habría, según él, un destello utópico, tema que deja enunciado, pero que no alcanza a profundizar en su análisis.

\section{LA CIUDAD DESDE EL EXILIO}

Adentrarse en la obra poética de Gonzalo Millán, con la tentativa de descifrar los signos que recorren con mayor insistencia La Ciudad, constituye un primer acercamiento a este libro clave de la poesía chilena. Obra que plantea la necesidad de asumir una voz de denuncia a través del acto de escritura, porque se trata de un libro escrito desde el exilio, por tanto, la patria que se vive en las fantasmagorías, las evocaciones y la añoranza. El discurso poético, saturado de repeticiones y de fórmulas, se vuelve monocorde y proyecta, así, un sentido elegíaco. Estos y otros son algunos de los recursos empleados para dar cuenta de la evidencia deshumanizante y degradatoria en que ha sido sumida la ciudad. Es decir, este libro puede ser visto como la culminación de un proyecto artístico en que se despliega una situación de emergencia social y cultural que irrumpe en las vidas de los habitantes, bajo el contexto de dictadura. La ciudad se construye, entonces, desde la lejanía mediante la evocación. Señala Millán:

Y así fueron surgiendo sobre el papel fragmentos aislados de escenas urbanas: un cerro tutelar, un río que arrastraba cadáveres, esquinas vigiladas, transeúntes fugitivos, voces y trazos de anónima rebeldía, acompañados en sordina por un rasgueo continuo de pluma y de guitarra. Y luego la imagen de la ciudad virtual, imprecisa y remota, emergiendo a duras penas entre los pañales o sudarios de smog que la envolvían; producto tanto de la imaginación como de la memoria: conocida e irreconocible, amada y a la vez repudiable. ("Sobre la construcción" 7)

En este sentido, la poética del exilio sitúa la mirada del sujeto sobre el lugar de origen, lugar que se ha perdido y que impone al desplazado vivir una vida impuesta en un medio extraño y ajeno. Así, esto cultiva una conciencia poética marcada por la necesidad de reconstruir la propia existencia, la propia voz, de manera que esto trae como resultado una reinvención del lugar de origen, ya perdido, y que se plasma a través de la palabra en cuanto evocadora del sentido de pertenencia, como también de 
la memoria; dos elementos vitales para la creación literaria en su dimensión liberadora. La memoria, así, es capaz de recuperar, al menos en algún sentido, aquello que se vive desde el anhelo. Gracias a ella el destierro se vuelve soportable, o quizás, un vehículo para reconstruir la existencia fracturada.

El exilio de Gonzalo Millán está marcado por las circunstancias políticas que se viven en su país de origen: el derrocamiento de Salvador Allende, el ascenso de la dictadura de Pinochet tras un golpe de Estado y, con ello, una ley brutal que se cierne sobre cualquier entidad o persona que parezca atentar contra este nuevo régimen. El exilio político, en este sentido, constituye no solo la expatriación del individuo, sino también un modo de resistencia de quien lo vive, contra la represión y la mordaza. El exilio, bajo este punto, no significa un escape, porque, en primer lugar, no es voluntario y, en segundo término, representa la única salida, a modo de sobrevivencia. Millán sale al exilio, y el país que lo acoge es Canadá. ${ }^{5}$ Allí, a seis años del golpe, en 1979, publica La Ciudad, bajo el sello editorial Maison Culterelle Québec-Amérique Latine. En este libro se tematizan y acentúan las problemáticas de una ciudad constreñida, asfixiada por un sistema totalizador y opresor. Aparecen las luchas de los habitantes para resistirlo, la vida del día a día en una cotidianidad bajo amenaza. La mirada del sujeto, del yo poético, aparece en un comienzo distanciada en la enunciación, puesto que detrás de ello reside un intento por explicitar el estado en que se encuentra la ciudad. Sin embargo, la inserción del "yo" y del "nosotros" en cuanto pronombres, generalmente alude a una victimización, que se condice con las circunstancias político-sociales graficadas.

Respecto de las ediciones de La Ciudad, cabe hacer algunas precisiones en torno a las diferencias que se presentan entre la de i979 y la de 1994. Lo primero que cabe señalar, es que casi dos décadas distancian a ambas, gestándose un largo paréntesis sobre el cual ha habido no solo cambios de una edición a otra, sino también movimientos continuos y regresivos, traslados y estancias en países diferentes por parte del autor. Esto marca un sentido de transitoriedad y errancia, lo que se plasma en el propio texto. La versión de 1979 finaliza con el poema 68, en su orden de disposición, anunciando la culminación del poemario: "El atleta alcanza la meta. / El andinista alcanza la cumbre. / Al final de la vía férrea hay un tope. / El poema llega a su término. / El anciano finaliza el poema ... Se cierra el poema." (Millán II9). Dicho poema, en la edición de 1994, fue trasladado por Millán al número 73 en orden de aparición, por lo que, al evidenciarse la introducción de nuevos poemas, se puede llegar a determinar la presencia de cambios de sentido sobre el conjunto. Algunos 
de estos, de tal modo, pueden hacernos pensar que nos encontramos frente a un texto diferente, pero que guardan entre sí una estrecha relación. Foxley señala, en este respecto, que el paso de una edición a otra, "no excluye, tampoco complementa, pero los relaciona a nuevas constelaciones de sentido" ("Lo móvil" 133).

De este modo, entre los cambios que más resaltan de la primera edición de 1979 a la de 1994, se presenta la sustitución del género del anciano. Tal personaje representaba la voz del fundador/escriba, localizado desde dentro y que suministraba un cierto tipo de discurso al hablante, quien lo recibía, canalizaba y transmitía, contribuyendo a convertir, después de la intervención de su propio discurso, en uno situado desde la hibridez. El cambio de género de este personaje, trae consigo algunos cambios de significación y de sentido, lo que vuelve aún más imprecisa su naturaleza. Si antes se podía afirmar que el anciano constituía una voz agónica y debilitada por su longevidad, ahora la sustitución de género problematiza todavía más la noción falogocéntrica, ya obsoleta tras la apuesta feminista, de que el varón es quien tiene el poder fundador. No obstante: "En el caso de la ciudad latinoamericana, el predominio de lo masculino se hace ya evidente en la ceremonia ritual del acto fundacional" (Guerra 290). En esta edición, así, la anciana toma el rol fundador/escriba, por lo que se invierten las jerarquías y roles de género, dando cuenta con esto de la posibilidad de mutar junto con y a través del texto. Pero aún más, en una suerte de desdoblamiento con el hablante lírico, la anciana pronuncia aquel dictado de la conciencia, a la par mientras escribe y siente el agobio: "A la anciana le faltan fuerzas. / La anciana puntúa. / La anciana deja la pluma. / El punto es diminuto" (Millán 88). Fundar la ciudad, entonces, es un acto que finalmente la consume, hasta que al término del poemario esto se traduce en su propia destrucción, porque el poema ha culminado.

Según lo anterior, en la edición de 1994 aparecen nuevas marcas textuales, lo que establece la existencia de una escritura de superposiciones. Así, como he señalado en páginas anteriores, en esta versión encontramos La Ciudad de 1979 como telón de fondo, pero a esta se le han agregado otros poemas y también algunas correcciones del autor. Es decir, se gesta una escritura de palimpsesto, lo que da cuenta de su permanente construcción. A su vez, la inclusión del penúltimo poema evoca una atmósfera más esperanzadora y auspiciosa. Del llamado a luchar y a resistir contra las fuerzas antagónicas, el hablante exhorta, en la edición de I994, a defender las libertades alcanzadas tras la recuperación de la democracia. En el contexto postdictatorial esta última era todavía un bien vulnerable y su pérdida implicaba un riesgo latente, especialmente 
durante el período de la Transición. El hablante enuncia: "Árbol de la esperanza. / Creciendo en el borde. / Del abismo. / Con la mitad. / De las raíces al aire. / ¡Mantente firme!” (I25). Estos destellos esperanzadores, hacen aflorar una valoración al sentido reconstructor de la ciudad. De este modo, subyace aquí una intención vindicatoria con aquellos que fueron aplastados por el sistema dictatorial (torturados, desaparecidos, familiares de las víctimas, exiliados políticos, etc.), e indica el deseo de mantener vivo su recuerdo en lo que supone la constante búsqueda de justicia y reparación.

Otro de los aspectos que llaman la atención, está referido a la culminación del libro con el poema número 73. Dicho número, difícilmente azaroso, evoca al momento en que la fractura dictatorial se instaló sobre la ciudad. Así, este representa el punto en que el mismo poemario comienza a gestarse, por lo cual el término de este significa el cierre de un ciclo, concluido en su propio origen de datación, de modo circular. En este sentido, La Ciudad es un libro del exilio porque el mismo autor dispone en el colofón de la primera y segunda versión, lo permanentes ires y venires transitados en este viaje. Pero en la edición de 1994 consigna, a modo de viaje mítico, el regreso a la patria, regreso del libro a su fuente original, de manera que el círculo nuevamente se completa y, así, se cierra: "Santiago de Chile, septiembre de 1973. / San José, Costa Rica, enero-agosto I974. / Fredericton, Canadá, agosto de 1974 - agosto de 1976. / Ottawa, Canadá, agosto de 1976 - noviembre 1979. / Santiago de Chile, septiembre de 1994" (I27; énfasis mío). La fijación de la fecha instala un problema de dataciones. Primero, porque hay una multiplicidad de tiempos. Segundo, porque cada una de estos indica un término. ¿Cuál es, entonces, la datación que fija el momento en que la obra se ha concluido? De esto, cabe señalar que precisamente en esta indeterminación se demuestra que estamos frente a un texto del exilio: la salida, el movimiento intermedio y el regreso, al igual que el viaje homérico. Pero, además, destaca la particularidad de que la gestación del libro data en pleno momento en que se instaura la dictadura (que puede asociarse a la violencia límite). El regreso, por su parte, se da en pleno proceso de transición a la democracia, es decir, el retorno de un orden anterior. ${ }^{6}$

En esta poética del exilio se aborda la crudeza de los hechos, los cuales se expresan desde los más triviales actos, como cruzar la calle, hasta las más radicales decisiones de los poderosos, y que marcan el destino de una nación. Millán recrea la ciudad que está en su memoria, la de su infancia y juventud, y cuyo sentido de pertenencia es abruptamente interrumpido, con excepción del lazo afectivo que perdura gracias al recuerdo. Así, es el distanciamiento lo que posibilita esta aguda forma de mirar, porque él 
mismo ha sufrido las consecuencias de la violencia dictatorial. La escritura es, por lo tanto, un mecanismo de defensa y de sobrevivencia. La posibilidad de recuperación de la ciudad perdida y distante, por los efectos del exilio, se realiza a través de su evocación mediante el lenguaje, representando la ciudad en palabras. Más allá de ser la patria física, a mi juicio extiende su simbología a la morada originaria en que se habita, la cual es también una construcción simbólica. Se gesta, bajo esta intención, que a través de la escritura es posible re-habitar la ciudad, o habitarla desde un sitio distinto, es decir, desde una materialidad ficcional, por cuanto:

Aquel que vive la ciudad, simultáneamente la inventa, la redice y contradice desde su propia subjetividad. Su percepción y su experiencia, insertas en un contexto corporal, social y cultural, crean así fracturas y remodelizaciones del espacio urbano dando paso a la imaginación, a otros signos, imágenes y narrativas que configuran otra topología simbólica, ajena a los nítidos trazos de cartografías e imaginarios hegemónicos. (Guerra 287-88)

Pero dicha ciudad que se construye se encuentra bajo latente amenaza, gestando un temor colectivo generalizado, visto desde la particularidad de los sujetos víctimas: "Cuchicheamos por última vez. / En el furgón frigorífico. / Como almejas entreabiertas. / Apenas en un plato de lata. / Luego con las bocas cerradas. / Morderemos el frío cuchillo." (Millán 32). Como puede observarse, la respuesta más radical y con mayor efecto de denuncia es el silencio, que actúa no solo como mecanismo de defensa, sino también por causa de la represión. La ciudad, vigilada y oprimida, entonces, se encuentra bajo una mordaza que el autor intenta desbaratar a través de su escritura.

Ahora bien, el libro se inicia con un poema que marca un camino a recorrer, una ruta donde el sujeto de la enunciación aparece distanciado del sujeto del enunciado. Esta actitud devela la necesidad de mostrar una realidad objetiva, para graficar el estado en que se encuentra la ciudad. El poema comienza con un "Amanece. / Se abre el poema. / Las aves abren las alas. / Las aves abren el pico. / Cantan los gallos. / Se abren las flores" (Millán 9). La ciudad, de este modo, empieza su estado de alerta; despertar iniciático que despabila y produce el movimiento. Lo interesante es que, junto con ese despertar de la ciudad, el poema se abre y, paralelamente, también la poesía es la que despierta de un sueño nocturno (de oscuridad, que puede asociarse con la dictadura militar) que se va dejando con los primeros rayos del sol. Este primer paso puede entenderse como el gesto por explicitar ese largo sueño en el que ha estado sumida la ciudad. Por lo 
tanto, la iniciación del poema responde al despertar de la conciencia y al primer llamamiento a ver y recorrerla. De este modo, se va dando paso, desde dicha alerta y por técnica de acumulación, a signos que introducen negatividad y peligro; fuerzas destructoras que amenazan la seguridad en la ciudad. Por esto, las fuerzas de negatividad comienzan a tematizarse al interior del poemario, mostrando las alteraciones sufridas por los habitantes, quienes deben replegarse y ocultarse en el ámbito privado. Con ello, empiezan a aflorar los conflictos sociales, económicos y políticos al interior de la urbe.

El despertar de la ciudad, a partir de los signos de negatividad antes referidos, expresa los miedos y las luchas irresueltas de los habitantes en su sobrevivencia diaria. El movimiento representa un transitar los espacios de la ciudad, pero también el sentido de alerta que imponen las amenazas y la necesidad de encontrar refugio: "Se abren navajas tijeras. / Corren pestillos cortinas" (9). De este modo, la ley del movimiento adquiere una significación peligrosa: los habitantes corren, se escabullen y buscan resguardo, puesto que la ciudad está sitiada y, como señala Beatriz Sarlo: "[La violencia] alimenta un sentimiento de inseguridad colectiva que se ha convertido en una pasión: la pasión del miedo como organizadora de la relación con el espacio público" (206). La violencia, así, constituye el panorama sobre el cual se establecen las interacciones de los sujetos en la ciudad, lo cual, bajo la amenaza dictatorial, se exacerba y gesta una paranoia colectiva, donde cualquier "otro", incluso un pariente o amigo, puede transformarse en un posible verdugo o delator. En este contexto, la poética del exilio millaniana, se alza como una voz no solo de protesta, sino que posee un fuerte carácter transgresor y, sobre todo, la condición de destierro se sitúa como una posibilidad de proferir denuncia. La palabra poética, entonces, posee una dimensión dialógica con lo social, aunque no cae en lo panfletario - que tanto abunda en épocas de fuertes crisis políticas - ni tampoco en simplismos que reduzcan la situación contingente que se está poetizando. Millán consigue, de este modo, "abrir el poema" y, así, señalar la situación compartida colectivamente, como una actitud que revela la necesidad de acción frente a la inercia y el silencio.

Cabe señalar que, si la utilización y reiteración de la estructura verbal es la constante, las variaciones residen en la utilización - explícita o implícita - del pronombre. Así, el impersonal "ellos", que se diferencia de un "yo" o de un "nosotros", es utilizado para denominar a cierto agente innominado y plural, cuyas acciones negativas generan una situación de desconfianza generalizada. Este pronombre da cuenta de un distanciamiento, es el "otro" del cual hemos estado refiriendo, y es quien disfruta del beneplácito del poder a costa del sufrimiento de los habitantes 
de la ciudad: "Pasa el tirano en un auto blindado"; "El tirano disfruta de salud" (Millán 15-6). Por otro lado, cuando se menciona el pronombre "yo", a menudo se está refiriendo a las acciones de índole cotidiana, como si la acción se estuviera realizando en forma paralela al acto de pronunciarlo. Ante la imposibilidad de que ese "tú" responda inmediatamente, aparece implicada la forma "nosotros", inclusiva y que concreta la imagen de un colectivo: "Vivimos amordazados. ... Vivimos con los ojos vendados" (I6); "Pasamos penurias. / Pasamos pellejerías" (83). Pero dicho colectivo, como se observa, es víctima y es a veces presa de ese "ellos" de la enunciación.

Los signos de negatividad que recorren y se anuncian con insistencia en la ciudad, se justifican por el trazado que la muerte ha ido dejando, marcando sobre la misma. La muerte incluye también las derrotas personales de los habitantes, derrotas dolorosas donde se incluyen el hambre, la mordaza y la injusticia, motivos por los cuales "Los ciudadanos caminan cabizbajos" (67), es decir, con el peso que la muerte les deja caer encima. Esta suma de muertes o derrotas personales, crea un cuadro en el que la ciudad misma se fragmenta, y a través de dichos fragmentos se conforma una constelación de intersubjetividades donde, simbólicamente, se trazan las fronteras de una ciudad derrotada. A través de dichos fragmentos, es que "La ciudad se segmenta y sus 'partes' son semantizadas de acuerdo a la experiencia de los sujetos" (Reguillo 173). Por ello, se establece una segregación de la ciudad, donde los lindes territoriales marcan fronteras físicas y simbólicas entre quienes disfrutan del poder político, social y económico -, y los que sufren a causa de los abusos de quienes lo ostentan.

A partir de cada experiencia individual, en este clima fúnebre, la ciudad es obligada a replegarse al ámbito privado. La expresión "toque de queda" proviene del ámbito militar, la cual fue trasladada en su uso por la dictadura a la ciudad, imponiendo, así, la restricción de guarecerse durante las horas asignadas por esta "ley del orden público". Esto conlleva una restricción "carcelaria" que impone, bajo amenaza de muerte, el encierro de los sujetos: "No imaginó jamás que el fragor. / Nocturno de un automóvil. / Infringiendo el toque de queda. / Encaminándose a su calle / Dirigiéndose a su casa. / Apuntando hacia su puerta. / Hasta detenerse fuera. / Capaz de enmudecer la ciudad. / Hacer atronador el silencio" (Millán 2I). Como se advierte en el poema, la amenaza recrea la experiencia persecutoria y, tal como lo expresa Hopenhayn: "el sentimiento difundido de inseguridad lleva a que las personas restrinjan su circulación en espacios públicos, eviten salir de noche o visiten ciertos barrios, se recluyan puertas adentro y busquen el esparcimiento en espacios privados" (83). Por eso, lo interesante es ver de qué manera se expande, 
desde el hecho particular, la potencia del crimen, por cuanto hace enmudecer a la ciudad, paralizándola en el silencio y el miedo.

Ahora bien, entre las fórmulas poéticas empleadas por el hablante, cabe destacar la inserción de proposiciones que introducen elementos de la naturaleza, a modo de analogía con la situación contingente, ya sea política, social o económica, pero por sobre todo para graficar los crímenes cometidos por la dictadura: "El mar se agita. / Los torturados braman. / Brama el mar. / Brama el viento entre los árboles. / El mar se enfurece. / El mar azota las rocas. / Azotan a los detenidos" (40). Como se advierte, el poema utiliza el efecto fonético para expresar la idea de fondo que contienen las aliteraciones. Así, los sonidos tónicos de las vocales abiertas, por simbolismo fónico, evocan espacios vastos, pero también expresan el sentimiento de dolor profundo y extenso. Esto, además, puede asociarse con la imagen de un mar agitado y que proyecta la convulsión dolorosa de la represión y la tortura. Pero también, en el uso mismo de la imagen, se estimula y potencia la capacidad analógica del lector, por cuanto se utiliza para conseguir efectos tanto estéticos como emocionales a nivel de la recepción, y también para dibujar el cuadro o escenario poético donde se despliega la fuerza vital de la naturaleza y sus ciclos regeneradores.

Por otro lado, la irrupción de elementos tales como los medios de masas, junto con un despliegue de inusitadas formas discursivas que se entremezclan con lo poético, dan cuenta de un discurso híbrido que rompe con la monotonía proposicional, dotándola de vitalidad y movimiento. A través de estas inclusiones, la ciudad se va codificando - o sobrecodificando - con un cúmulo inagotable de discursos fragmentarios, donde lo que interesa es, precisamente, la hibridez y el collage. Así, la ciudad se compone de una diversidad de signos que se resemantizan y adquieren nuevas connotaciones, muchas de ellas tomadas de otros discursos, como el científico: "Un sol de rayos equis. / Radiografía los bosques. / De ramas desnudas y mis manos. / Esqueléticas sin guantes" (Millán 38). El objeto representado, de esta forma, se constituye en la hibridez, lo cual viene dado como signo de los tiempos y como síntoma de la cultura de masas, tal como se aprecia en el siguiente fragmento: "La beldad se lava con champú ROSEDAL. / La beldad es rubia. / La beldad se tiñe el cabello. / Los lustrabotas tiñen. / La beldad se tiñe con tinturas GAMA" (75). Este personaje viene a representar a la cultura de consumo, es decir, el sujeto poético hace un guiño para expresar el empobrecimiento espiritual, dado en igual proporción con el enriquecimiento económico. Esto produce que el personaje y la situación sean satirizados y, asimismo, se muestre una frivolidad sintomatizadora de los tiempos, alegorizando 
con esto los efectos que el consumo atrae sobre los sujetos insertos en esta dinámica. ${ }^{7}$

Según lo señalado, el modelo de mercado irrumpe en la ciudad, de modo que este viene dado por el sistema económico impuesto por la dictadura que segrega y marca aún más las divisiones entre ricos y pobres. Los que tienen acceso a los bienes de consumo son los mismos que ostentan el poder: "El tirano se tiñe las canas con tintura GAMA". Acá subyace una crítica donde no solo se impugna a dicho sistema económico, sino, sobre todo, se critica la continuidad de un modelo diseñado por la dictadura y la postdictadura, que tiene por fin perpetuarse. Es decir, se trata de un modelo de impunidad de los crímenes y de secularización del poder. A su vez, tal como señala Luis Cárcamo-Huechante: "el mercado ya no es tanto un fenómeno de base material sino, sobre todo, simbólica" (IOI). Y bajo esta base, el mercado adquiere una fuerza avasalladora e, incluso, nociva para los propios consumidores que, sin darse cuenta, están consumiendo sus propias vidas para alcanzar nuevos bienes económicos, en esta dinámica mercantil.

De este modo, el discurso poético a momentos se torna satírico, de forma que la sátira es utilizada también para burlarse de la figura del dictador: "El cerdo tiene las orejas caídas. / Los anteojos se sujetan en las orejas. / El cerdo usa anteojos ahumados" (Millán 99). Este último verso, por alusión a la figura del dictador, quien en sus días de apogeo solía utilizar anteojos como un símbolo semiótico que infunde autoridad y produce temor o rechazo en el observador. De esta manera, ocultar los ojos es una forma de generar desconfianza, porque impone una barrera física que impide ver la expresión de la mirada. Asimismo, como versa el adagio popular, "los ojos son el espejo del alma", por lo que, si estos se ocultan o velan, se desprende que se debe a que es un sujeto impuro o perverso. Así, dicha imagen quedó registrada en el imaginario colectivo no solo chileno, sino en el contexto internacional, y bien puede ser el hipograma de este poema. ${ }^{8}$

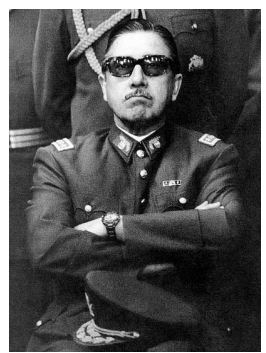

Fotografía realizada por Chas Gerretsen, 1973 
Ahora bien, los maniquíes representan "dramas urbanos en vitrina" (Silva 70). Su función consiste en la exhibición de la moda del momento, las prendas que se exponen en los escaparates para producir atracción en el espectador. De tal forma, en ellos se "encarnan" los intereses del mercado, atrayendo a los posibles consumidores y, así, "las vitrinas de las ciudades están dramatizando (y humanizando) el día y la noche" (72). Gonzalo Millán compone un poema donde la figura central son estos artefactos, prestando su figura "corporal" como un remedo portador del drama que refleja la deshumanización del ser humano. El poema comienza: "En las vitrinas hay maniquíes. / Los maniquíes son de yeso. / Los maniquíes están inmóviles. / Los maniquíes son elegantes. / Los maniquíes visten ropa cara. / Ropa nueva de primera mano" (Millán 22). Así, la figura de los maniquíes, a través del uso de la repetición y por ironía, exacerba las cualidades que los caracteriza. Los maniquíes pueden ser asociados con las momias, ya que presentan una figura humana inerte. Según esto, durante la dictadura militar, al bando político de derecha y simpatizante con la figura del dictador, se les denominaba "momios". Esto expresaba la idea de hombres y mujeres inertes que no desean ni permiten cambios. Como es sabido, la derecha tradicionalmente no se mueve hacia ideas progresistas, permanece estancada en su sitio. El término se acuñó por figura traslaticia de metagoge, atribuyendo cualidades perceptivas a un objeto inanimado. Incluso, había un grito popular que era entonado durante las manifestaciones públicas que versaba repetitivamente: “ $i E l$ que no salta es momio!"

Como se advierte en el poema, entre las cualidades de estos maniquíes, se cuentan la elegancia y que visten ropa cara. Más adelante esto se refuerza con que utilizan "ropa de primera mano". Ello supone no solo el acceso a los bienes de consumo, sino también al hecho de que esto lo exhiban. Además, el sujeto enuncia: "Los maniquíes no tienen frío. / Los maniquíes no tienen hambre. / Los maniquíes lucen saludables. / Los maniquíes son felices. / Están siempre sonriendo". Claramente se utiliza la sátira para representar a estos hombres pseudohumanos que, aparentemente, no tienen ni sufren de necesidades, tienen sus vidas resueltas, no pasan frío ni tampoco parece afectarles la contingencia dolorosa vivida en el país o, más aún, aparecen como beneficiarios de ella. La suma de lo anterior, da cuenta de que los maniquíes o "momios", vienen a ser los "otros"; sujetos distanciados de la realidad de quien enuncia el discurso y todas aquellas personas que resultaron víctimas de la dictadura.

Ahora bien, uno de los poemas que resulta central para este libro, se encuentra en el número 53 en orden de disposición, y dice: "El río invierte el curso de su corriente. / El agua de las cascadas sube. / La gente empieza 
a caminar retrocediendo. / Los caballos caminan hacia atrás. / Los militares deshacen lo desfilado. / Las balas salen de las carnes" (Millán 9r). Como se observa, este poema posee la particularidad de que en él se invierte el ciclo natural de la vida, en un movimiento regresivo que da cuenta de un retroceso de la historia. Desde los ciclos de la naturaleza, como el agua, se da paso al ciclo del movimiento humano: el de los habitantes o transeúntes que retornan a lo vivido en el pasado. Esto expresa una concepción imaginaria de un tiempo que vuelve a su punto inicial, sin que ello implique borrar el pasado ni mucho menos a sus muertos. La poética del exilio, entonces, presenta una visión nostálgica de la realidad, donde se evoca un regreso al "tiempo perdido". Solo a través de este regreso mítico es posible la sutura de la herida, del dolor imborrable, lo que permite que se desencadene una dinámica encantatoria.

Porque algo de magia hay en este regreso, un regreso que necesariamente conlleva revisitar el pasado y revivirlo en el presente: "Los campos de concentración se vacían. / Aparecen los desaparecidos. / Los muertos salen de sus tumbas. / El patio 29 se vacía. / ¿De quién son los huesos de la bolsa 20? / Los aviones vuelan hacia atrás". De este modo, el poeta logra invertir el paso del tiempo, representándolo en una inversión que configura una fuerza esperanzadora. Pero surge también una forma de expresar la nostalgia: "II de septiembre. / Regresan aviones con refugiados. / Chile es un país democrático ... Renace Neruda." Y en este regreso, las víctimas resurgen para tomar el cauce que les habría correspondido seguir: "Víctor Jara toca la guitarra. Canta." De esta forma, los muertos reaparecen y su regreso trae inevitables cambios sobre la ciudad. El poema continúa en esa inversión del tiempo, de modo que: "El tirano abraza a Prats. / Desaparece. Prats revive. / Los cesantes son recontratados. / Los obreros desfilan cantando. / ¡Venceremos!” Este último grito, lema de la Unidad Popular, puede ser interpretado de dos maneras: como un grito ya obsoleto, que responde al "museo del pasado que antecedía a la destrucción de la ciudad y que fue arrasado en esa misma destrucción: es decir, el remedo de la izquierda de viejas consignas y el relego de la política al espacio del museo" (Leal, "El regreso"). Pero puede ser visto también como la validación de esta nueva esperanza, de un repetir el aliento de coraje e ímpetu que inspiraba el sentido de lucha y que permitía la cohesión social en las ideologías. El hipograma del poema, en

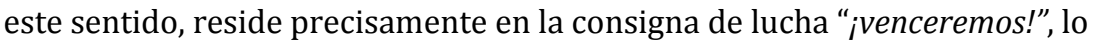
cual se demuestra con la retroacción que va reconstruyendo inversamente el tiempo, hasta llegar a ese punto donde surge la exclamación colectiva. El venceremos señala el punto de bifurcación de la historia real hacia una imaginaria y, por ende, de reivindicación del poder popular. 
HABLAR DESDE EL SILENCIO

¿Qué expresa el silencio cuando no se dice la palabra silencio?, ¿hablar desde la imposibilidad de decir, o quizás, decir aquello que no se puede expresar sino desde el mutismo? En La Ciudad se gestan estas preguntas y paradojas. Revisando de qué manera el silencio comunica, a través de metáforas y metonimias, es posible aprehender un mensaje que revela una visión de la realidad. De este modo, por ejemplo, el poema número 5 en orden de disposición, va anunciando las restricciones del habla que también han sido impuestas, hasta culminar con la noción de "vivir amordazados". En él enuncia: "Vvms mrdzds. / Vvmos mrdzdos. / Vivimos mordazados." Hay una suerte de onomatopeya que reproduce el acto de decir "vivimos amordazados", por lo que se establece un paralelismo entre el acto de pronunciarlo y el de vivirlo. Esto constituye una isotopía fonológica, por la iteración de sonidos, que reproduce también la isotopía semántica o del significado: el sonido que se emite mientras se está amordazado, impedido de hablar a la fuerza. Esta forma de decir ya la había anticipado Vicente Huidobro en algunos pasajes de Altazor, aunque con algunas diferencias. Allí el poema finalizaba con una descomposición total y radical del lenguaje, desarticulado por la visión de la caída que atrae la muerte. Con eso quedaba también de manifiesto la incapacidad del lenguaje verbal para expresar aquello que supera a las palabras. En La Ciudad, en cambio, la recurrencia al silencio tiene nuevas y diferentes significaciones: un intento de volver a lo primordial que parte desde el vacío y la desolación. Aquí encontramos algunas conexiones con el libro del poeta creacionista, ya que el silencio acá anuncia, en reiteradas ocasiones, el clima fúnebre de la dictadura.

No obstante, paradójicamente el poemario comienza desde la premisa de romper el silencio, de modo que la iniciación del poema significa una alteración del mundo a través de la palabra: "Amanece. / Se abre el poema. / Las aves abren las alas ... Corre la pluma. / Corre rápida la escritura" (Millán 9-IO). El ejercicio de escritura atrae, de este modo, una primera resistencia al silencio, la cual irá adquiriendo distintos matices, según la función que vayan adquiriendo las proposiciones dentro de los poemas. El sujeto poético, en tanto que va efectuando una acumulación de distintas versiones de lo que refiere a través del acto de nombrar, logra dimensionar las diferentes miradas sobre los hechos que acaecen sobre y contra la ciudad. De esto se desprende, así, la necesidad de incorporar el conjunto de realidades vividas por los habitantes, las cuales conforman una suerte de "tejido" social violentado por la dictadura. No lo hace, sin embargo, mediante la mera descripción, sino también a través de fórmulas poéticas que enfatizan el sentimiento de desolación que aqueja a los ciudadanos. En 
consecuencia, el uso de metáforas y metonimias que aluden al silencio, constituye uno de los principales recursos poéticos para graficarlo: "Disimular la ira. / Disimular el disgusto. / Disimular la pobreza. / Disimular el hambre. / Morderse la lengua. / Obrar con mucho disimulo" (I7; énfasis mío). Como puede observarse, la metonimia indicada da cuenta acerca de la autocontención o refreno de aquello que se quiere expresar, graficando la imposibilidad de poder hacerlo a causa de la represión dictatorial. Esta metonimia muestra muy bien la idea de amenaza que se instala en el imaginario colectivo, por cuanto relega a los habitantes a la autocensura, el disimulo y, en definitiva, al silencio. Como bien lo ha señalado Adriana Valdés:

Después del golpe militar en Chile, la literatura, por una parte, y la plástica, por otra, realizaron su actividad en torno a un vacío: el de las palabras suprimidas, el de las imágenes suprimidas; en el límite, en el de los cuerpos desaparecidos. El miedo impedía hablar de cosas cuyo impacto emocional y vital era tremendo para mucha gente. (138)

Se gesta, de tal manera, un silencio que establece el peligro de atraer el desaparecimiento. $Y$ bajo esta premisa, el silencio adquiere una significación dramática y radical, puesto que en estos términos solo se puede vivir en los opuestos: la inercia o la lucha: "Apareció. Había desaparecido. / Pero apareció. Meses después. / La encontraron en una playa. / Meses después con la columna. / Rota y un alambre al cuello" (Millán 47). Por eso, la posición menos riesgosa es la de abstraerse en complicidad con la dictadura, no asumiendo el riesgo de lanzarse al abismo, contrario a lo que muestra, como efecto, este poema. Así, aquellos que se atreven a romper el silencio, a actuar, peligran sus propias vidas. En el mismo poema 5, el silencio adquiere nuevamente una significación mortuoria, con todo el sentido elegíaco premunido. Allí, "Pasan carrozas. / Por esta calle pasan entierros. / Pasaron a muchos por las armas. / Las calles tienen muchos baches. ... Pasa un enano con una gran cabeza. / Pasa el tirano en un auto blindado" (Millán 15). Desde los primeros versos, es posible evidenciar que el verbo "pasar", en sus distintas conjugaciones, cumple la función de marcar un recorrido doloroso por los espacios de la ciudad. Es decir, se marca un tránsito que se asocia con negatividad. Los que pasan son un "ellos", es decir, quienes crean un ambiente de sospecha y amenaza. Las carrozas, así, constituyen la imagen de una procesión fúnebre, que puede ser vista por cualquier transeúnte de la ciudad, como en un espectáculo del horror. Es la imagen viva de la muerte y produce un 
impacto visual que retrotrae al dolor y la pérdida de los deudos, y al dolor experimentado por la tortura de dichos asesinados.

Cabe destacar, también, que en la medida en que los habitantes de la ciudad son relegados al silencio, a causa del miedo y la amenaza, la ciudad, en su geografía simbólica, también se encuentra amordazada. En otro poema, el sujeto enuncia: "Capaz de enmudecer la ciudad. / Hacer atronador el silencio" (2I). Con esto, se establece que el silencio es la respuesta a una experiencia traumática, donde la constante es la acechanza y el asedio de los sujetos. De tal forma, lo que se busca es resistir ante la represión y la violencia, por lo que los habitantes de la ciudad tratan de soportar la situación de precariedad, experimentando el deber de sobrevivir en medio de la angustia. La ciudad, de esta manera, se vuelve un escenario de constantes resistencias a la amenaza latente. El efecto de esto último es llevado a su extremo en el poema I5. Allí, "Pide saliva. / En la boca. / Seca de miedo. // El silencio. / Y la palabra. / Matan. // De la garganta. / Brota de golpe. / El grito. / De agua" (Millán 28). Con esto, se establece que una de las estrategias de la dictadura para preservar su potestad es infundir miedo, puesto que este paraliza a los sujetos, los mantiene en un estado de inercia y, por antonomasia, los relega al silencio. El silencio es una actitud que puede ser entendida desde, al menos, dos ángulos. El silencio como respuesta al miedo (la parálisis frente a la amenaza) y, por otra parte, el silencio cómplice que establece una falta ético-valórica. Como señala Reguillo: "Históricamente, el miedo ha sido un instrumento de control y opresión" (179), y en ese sentido, el miedo instala una mordaza en el imaginario urbano, constriñendo aún más las interacciones de los sujetos en la urbe.

En el penúltimo poema de la edición de I994, el hablante lírico efectúa un recorrido por aquellas formas utilizadas por la dictadura para paralizar, castigar y oprimir a los ciudadanos. No obstante, aparecen también aquellas resistencias de estos últimos para sobrevivir y, en este contexto, volver a la vida. El poema, de este modo, atrae un sentido rearticulador, por cuanto: "El corazón late. / Las arterias laten. / La resistencia está latente. / Los pies sostienen. / Los dispersos se reagrupan. / La pierna media entre la cadera y el pie. / Los pies caminan. / La resistencia se rehace" (Millán I23). Gracias a este nuevo latido, los ciudadanos restablecen sus vínculos antes perdidos, la sociedad comienza un proceso de reajuste, de manera que los miedos comienzan a desaparecer y, así, las voces empiezan a oírse nuevamente: "El corazón palpita. / Los obreros van a la huelga. / Mientras existe el corazón existe la vida. / La dictadura es reversible. / No perdurará la dictadura. / Reafirmamos nuestra voluntad de lucha. / El corazón tiene el tamaño de un puño" (I24). Las metáforas 
relacionadas con ciertas partes del cuerpo, expresan el sentido rearticulador que he venido señalando, ocurriendo algo semejante al proceso de sanación de la fractura física. De tal forma, detrás del clima de esperanza, reside una voluntad, o más bien, una certeza de que la dictadura es incapaz de sobrevivir ante la resistencia popular. En este sentido, como ha señalado María Rosa Olivera-Williams:

La grandeza del poema de Millán es haber sabido construir, siguiendo una determinada dirección de la poesía hispanoamericana, "la patria", no como imagen del país que dejó, no como producto de la acción deformante de la distancia temporal y espacial, sino como signo de la fragmentación impuesta por la dictadura y de la voluntad del pueblo y del escritor, rama de ese mismo árbol, de cerrar el vacío entre "el afuera" y "el adentro", de hilvanar los retazos, los fragmentos. El pueblo en la ciudad sobrevive, mantiene vivo "el raigón" del árbol talado, y el escritor desde afuera con su trabajo va tejiendo el texto de una patria que busca su unidad. (136)

De este modo, la voz del pueblo es capaz de vencer al silencio, destruirlo mediante la cohesión social, es decir, gracias a la unión de los ciudadanos. Esto último, gestándose una fuerza solidaria e indestructible que se resiste a ser sometida nuevamente por la represión dictatorial.

\section{Providence College}

NOTAS

I La promoción de poetas del sesenta está marcada por un sentido de comunidad que los agrupaba. Eran reticentes al calificativo de "generación", considerándose una "promoción emergente". Muchos de ellos se vieron impelidos de partir al exilio tras el golpe de Estado de i973. Entre estos autores, se cuentan a Gonzalo Millán, Óscar Hahn, Manuel Silva Acevedo y Waldo Rojas. Para profundizar más sobre esta promoción de poetas, véase la tesis doctoral de Magda Sepúlveda y el artículo de Waldo Rojas. Además, otra referencia de importancia para su estudio es la compilación de entrevistas reunidas en el libro de Soledad Bianchi de 1995. Consultar apartado bibliográfico.

2 Según consta en el artículo de Carmen Foxley que cierra la edición de I994 de La Ciudad, en la versión de 1979 Gonzalo Millán había introducido ya dos poemas de un libro posterior, titulado Vida y publicado en 1984 , lo cual demuestra su interés en dar cuenta de la movilidad de los textos. 
3 Asimismo, María Inés Zaldívar ha desarrollado líneas de investigación sobre la temática del erotismo en la poesía de Millán.

4 Gonzalo Millán, en la edición de 1994, sustituye el género del anciano, denominando a este personaje como "la anciana". Más adelante en este artículo ampliaré sobre este y otros cambios. Ahora bien, considerar que el discurso es pronunciado únicamente por el anciano, resulta insuficiente, ya que, en mi lectura creo que más bien se gesta una suerte de desdoblamiento por parte del hablante lírico, estableciéndose una superposición de discursos a modo de palimpsesto.

5 Durante su estadía en Canadá, Millán se reúne con otros poetas chilenos de su generación y fundan una editorial que se encarga de difundir a escritores chilenos en el exilio. Al respecto, Millán escribe: “En Ottawa me encontré con algunos poetas chilenos que habían integrado un grupo llamado Escuela de Santiago en la década del sesenta. Con Jorge Etcheverry, Leandro Urbina y otros compatriotas fundamos una editorial, "Cordillera” y un taller literario del cual fui director" ("Sobre la construcción" 8).

6 Resulta problemático y hasta ingenuo asociar a la democracia con un "orden", ya que sabemos que todo "orden" puede encerrar, de base, un "des-orden", pero acá lo utilizo en el sentido más amplio de la palabra. Por otro lado, si bien las distancias históricas y literarias entre la obra homérica y La Ciudad son conspicuas, se evidencia que, justo al momento en que se desata la inversión del orden en La Odisea, Ulises sale de la patria, y a su regreso nuevamente este se restituye. Cabe precisar, eso sí, que no fue un intento de Millán semejarse a la figura del héroe trágico, pero sí hay un gesto fundacional en La Ciudad, el que se corresponde con la reconstrucción de la patria o el lugar de origen a través de su evocación.

7 Linda Hutcheon señala que, entre los requisitos de la sátira, se cuentan el humor basado en la fantasía, lo grotesco o lo absurdo y alguien o algo que atacar. Posee un propósito moralizante, por cuanto busca corregir una falla de índole moral y pone al descubierto, a través del ataque, defectos precisos y reales de quien se ataca, en una actitud desvalorizadora.

8 Michael Riffaterre propone el concepto de hipograma, entendiendo que el texto, por referencia a un elemento fuera del mismo, y con el cual establece una relación, produce su significado. De este modo, el hipograma es un elemento presente en la cultura, pudiendo ser una frase, un clisé, una imagen, etc., que generalmente se graba en el imaginario social. Por eso, en cuanto sistema de signos que puede rastrearse fuera del texto, implica un ejercicio de conocimiento y de analogía por parte del lector. 
OBRAS CITADAS

BIANCHI, S OLEDAD. "La concentrada intensidad de Gonzalo Millán". Diario La Época, I8 de septiembre de 1988.

—. La memoria: modelo para armar; grupos literarios de la década del sesenta en Chile. Santiago de Chile: Dirección de Bibliotecas, Archivos y Museos; Centro de Investigaciones Diego Barros Arana, 1995.

CÁrcamo-huechante, luis. "Hacia una trama localizada del mercado. Crónica urbana y economía barrial en Pedro Lemebel". Más allá de la ciudad letrada: crónicas y espacios urbanos. Eds. Boris Muñoz y Silvia Spitta. Pittsburg: U of Pittsburg P, 2003. 99-117.

foxley, CARMEn. "Lo móvil, lo efímero, lo abierto: La Ciudad de Gonzalo Millán". La Ciudad, Gonzalo Millán. Segunda edición. Santiago: Cuarto Propio, I994. I29I44.

—. "La negatividad productiva y los gajes del oficio. La poesía de Gonzalo Millán". Seis poetas de los sesenta. Santiago: Universitaria, 1991. 54-86.

GUERRA, LuCíA. "Género y cartografías significantes en los imaginarios urbanos de la novela latinoamericana". Más allá de la ciudad letrada: crónicas y espacios urbanos. Eds. Boris Muñoz y Silvia Spitta. Pittsburg: U of Pittsburg P, 2003. 287306.

HOPENHAYN, MARTín. "Droga y violencia: fantasmas de la nueva metrópoli latinoamericana". El espacio urbano. Comunicación y violencia en América Latina. Ed. Mabel Moraña. Pittsburg: U of Pittsburg P, 2002. 66-9I.

HUTCHE ON, LINDA. A Theory of Parody: The Teachings of Twentieth-century Art Forms. Urbana: $\mathrm{U}$ of Illinois $\mathrm{P}, 2 \mathrm{OoO}$.

LEAL, FRANCISCo. "Interrumpir el golpe: arte y política en La Ciudad de Gonzalo Millán". Taller Letras 40 (2007): 203-220.

—. "El regreso de los muertos. La ciudad de Gonzalo Millán". Proyecto Patrimonio, 2006. S.pag. Web.

millán, gonzalo. La Ciudad. Santiago: Cuarto Propio, 1994.

—. La Ciudad. Ottawa: Maison Culterelle Québec-Amérique Latine, 1979.

-. "Sobre la construcción de La Ciudad". Lar: Revista de Literatura 7 (1985): 6-10. Nó M EZ, naín. "Identidad y exilio: poetas chilenos en Canadá". Céneca 8r (I986): I36.

olivera-williams, maría rosa. "Poesía del exilio: el Cono Sur." Revista Hispánica Moderna 4I (I988): I26-I42.

Rif ATt E RRE, michael. Semiotics of Poetry. Bloomington: Indiana UP, 1984. ROJAS, WALD O. "Emergencia y trayectorias de una generación: los 'Poetas del sesenta' en Chile". Taller de Letras 38 (2006): I4I-I63. Rojo, gríno R. Crítica del exilio. Santiago: Pehuén, 1988. 
—. "Poesía chilena del exilio: a propósito de La Ciudad de Gonzalo Millán". Ideologies \& Literature 17.4 (1983): 256-277.

SARLO, BEATRIZ. "Violencia en las ciudades: una reflexión sobre el caso argentino". El espacio urbano. Comunicación y violencia en América Latina. Ed. Mabel Moraña. Pittsburg: U of Pittsburg P, 2002. 205-215.

SEPÚ LVEDA, MAGDA. "Años 60 en Chile: historia cultural, imaginarios juveniles, hipogramas poéticos". Tesis Universidad de Chile, $200 \mathrm{I}$.

SILVA, ARMA N D o. Imaginarios urbanos. Cuarta edición. Bogotá: Tercer Mundo, 2000.

VALDÉS, ADRIANA. "Gestos de fijación, gestos de desplazamientos: algunos rasgos de la producción cultural reciente en Chile". Cultura, autoritarismo y redemocratización en Chile. Eds. Garretón Manuel et al. Santiago: FCE, 1993. I2I135 .

zaldívar, maría inés. La mirada erótica en algunos poemas de Ana Rossettiy Gonzalo Millán. Santiago: RIL, 1998. 